\title{
Research centre head quits in frustration at UK policy
}

London. Britain's efforts to boost the integration of basic and clinical research in gene therapy received a major setback last week with the resignation of Kay Davies, one of the country's leading geneticists, as director of the Medical Research Council's (MRC's) new Clinical Sciences Centre(CSC).

Davies was appointed in 1992 to head the centre, which is due to open later this year at the Royal Postgraduate Medical School, located at the Hammersmith Hospital in west London. Her experience in linking basic and clinical studies of various diseases, and in particular her work on the genetic basis of muscular dystrophy, made her an ideal appointment.

Since then, however, planning for the centre has become bogged down in political fighting over the government's reorganization of London hospitals, a move intended to address a combination of declining patient demand in the capital and the placing of health care on a 'purchaser/provider' basis.

Last month, the government approved plans to merge the Hammersmith Hospital and nearby Charing Cross Hospital. But it refused to supply the additional funding which, it had been told by leading scientific advisers, was needed in order to protect research programmes in any merger of the two institutions on a single site (see Nature 386, 177; 1994).

The government's decision seems to have been the last straw for Davies, who had spent the previous two years trying to recruit scientists to a centre whose future is now uncertain, and fighting unsuccessfully to persuade the government to provide for its long-term security.

"My decision to resign was based entirely on the fact that I had put two years of my life into fighting for something I have always believed in, namely linking basic research to its possible clinical applications," Davies said last week. "The CSC was a golden opportunity to do just that; now I just want to get on with my research."

Sir Dai Rees, secretary of the MRC, which has invested $£ 11$ million in the CSC — and had been hoping to persuade the government to subsidize a transfer to the Charing Cross Hospital - has expressed his "great regret" at Davies' decision. But he added that the opening of the CSC will proceed as planned, and that a search for a new director will begin shortly.

Nevertheless, the council faces an uphill task in restoring the credibility of a project that has been severely damaged - both practically and psychologically - by the government's decision on the Hammersmith/ Charing Cross merger and, now, by Davies' departure.
Those anxious about the future include a number of research groups from the MRC's Clinical Research Centre (CRC) at Northwick Park, which are due to move to Hammersmith when the CRC closes down later this year. "It has certainly had a demoralizing effect," says one scientist, claiming that various colleges of the University of London are now keen to offer the CSC (or at least some of its component parts) an alternative home to the Hammersmith.

"The impression that is left is of a country working without an endocrine system; no-one seems to know what anyone else is doing," he says. "Given the amount of work that went into preparing the Hammersmith proposal, it is going to be very difficult if things start to fall through at this stage."

There is also gloom at the Wellcome

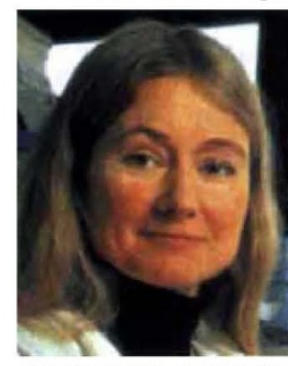

Davies: returning to the laboratory. Trust, which had already committed $£ 4$ million towards research facilities adjacent to the CSC laboratories in a new clinical research building at the hospital, and had agreed to support five research groups in the laboratories.

Bridget Ogilvie, the director of the trust, said last week that she was "sad, but not surprised" at Davies's decision, which she described as a "major blow" to the CSC. Given the uncertainties over the future of the Hammersmith, she said, the trustees are meeting soon to reconsider the trust's position. "We are still discussing what our options are," said Ogilvie.

Davies is reluctant to talk of her own plans, beyond the fact that in the short term she intends to devote her efforts to the work of her research group at the Institute of Molecular Medicine at Oxford. But she is rumoured to be a strong candidate for the position of professor of genetics at the University of Oxford, which could be combined with responsibility for some of the genetics work carried out at the MRC's Radiobiology Unit at Harwell.

Ironically, Davies chaired an expert working group that recently reported on the state of genome research in the United Kingdom (see Nature 368, 675; 1994). The report argued the need for Britain to exploit both its scientific strengths in human genetics and the opportunities offered by its clinical base through the National Health Service. The events surrounding the CSC indicate that, in the current political climate, achieving synergy between the two is considerably easier said than done.

David Dickson

\section{Rhône-Poulenc to focus biotech work on gene therapy}

Paris. Gene therapy in France has taken a big step from the laboratory bench to the hospital bed with the decision by RhônePoulenc-Rorer (RPR), the pharmaceutical subsidiary of the Rhône-Poulenc group, to concentrate its biotechnology business on cancer gene therapy.

To do this, RPR has set up a new division, known as Biotech. This regroups RPR's biotechnology activities, including the 250 staff at its biotechnology centre at Vitry in the south of Paris, and its 37 per cent stake in the US start-up gene therapy company Applied Immune Sciences.

Moreover, in a novel approach to the organization of drug research in large companies, RPR has offered the new division the freedom of an independent biotechnology company. It may eventually be floated on the stock exchange.

RPR had tentatively explored gene therapy through collaborations with academic research teams. "We've now decided that we can do it [commercially]", says Jean-Bernard Le-Pecq, scientific director of Biotech.

One reason for plunging head first into gene therapy, admits Le-Pecq, is that RPR missed the boat in the development of recombinant drugs, and watched while its competitors captured all the obvious candidates, such as growth hormone. "It was an interesting page of pharmaceutical history, but written by others," he says.

But Le-Pecq says that setting up an industrial strategy for gene therapy poses an unprecedented problem, namely that the intellectual property rights to gene therapy techniques are held by academic groups and biotechnology companies. "It's like trying to build a railway when different people own the trains, the rails, and the signals."

$\mathrm{RPR}$, he says, is at present involved in persuading patent holders to pool their intellectual property rights in order to speed up the transfer of gene therapy from the laboratory to the factory. A network similar to that of the software company Microsoft is the most probable outcome. One natural node will be the Généthon laboratory in Paris, which has launched two large gene therapy programmes (see Nature 365, 686; 1993).

RPR's parent company, Rhône-Poulenc, is itself shortly to launch a major programme in chemistry corresponding to the five-year, FFr1,600-million programme launched jointly with the government in 1991 in the life sciences.

Chimie-Avenir, as it will be called, will probably involve not only Rhône-Poulenc but also other industrial groups such as Lafarge-Coppeé, Saint-Gobain andBouygues. 